\title{
Minerals that Host Metals at Dorowa Rock Phosphate Mine, Zimbabwe
}

\author{
M. L. Meck ${ }^{*}, 1,2$ J. Atlhopheng ${ }^{2}$, W. R. L. Masamba ${ }^{3}$, S. Ringrose ${ }^{3}$ and S. Diskin ${ }^{3}$ \\ ${ }^{I}$ Department of Geology, University of Zimbabwe, P.O. Box MP167, Mt. Pleasant, Harare, Zimbabwe \\ ${ }^{2}$ Environmental Science Department, University of Botswana, Private Bag UB0704, Gaborone Botswana \\ ${ }^{3}$ Harry Oppeinheimer Okavango Research Centre (HOORC), University of Botswana, Private Bag 285, Maun Botswana
}

\begin{abstract}
This study set out to establish the major minerals at Dorowa and determine which of those are likely to host metals that may leach into surface and groundwater. This study comes after a preliminary assessment of the water quality in the Save River downstream of the Dorowa phosphate mine in Zimbabwe showed an increase in conductivity, iron content, manganese content, nitrates and hardness when compared to those taken before the mining area. X-Ray Diffractometry (XRD) was used to establish the major minerals at Dorowa whilst Inductively Coupled Plasma Mass Spectrometry (ICP-MS) was used to establish the chemistry of the rocks. The results from this study show that the major minerals in the rocks around Dorowa are feldspars, pyroxenes, apatite, magnetite and calcite. The metals hosted by the rocks include $\mathrm{Ag}, \mathrm{As}, \mathrm{Be}, \mathrm{Cd}, \mathrm{Co}, \mathrm{Cu}, \mathrm{Pb}, \mathrm{Hg}, \mathrm{Ni}, \mathrm{Sb}, \mathrm{Se}$ and $\mathrm{Zn}$. The study concludes that the minerals likely to host metals are calcite and apatite. Metal hosting is higher in apatite minerals than in calcite. Metal hosting by the other minerals observed in the study area is low.
\end{abstract}

Keywords: Igneous Rock phosphates, metal host.

\section{INTRODUCTION}

Igneous rock phosphates are currently being mined at Dorowa mine in Zimbabwe (Fig. 1). The measured rock phosphate resource at Dorowa is 73 million tonnes phosphate rock with an average grade of $6.6 \% \mathrm{P}_{2} \mathrm{O}_{5}$ giving approximately 4.82 million tonnes $\mathrm{P}_{2} \mathrm{O}_{5}$ [1]. According to [2] and [3] rock phosphates may contain heavy and radioactive elements considered to be toxic to humans and animals. The heavy metal and radionuclide content varies according to the geologic setting of the mining area [4-8]. In general, sedimentary phosphates contain much higher concentrations of potentially harmful elements $(\mathrm{Cd}, \mathrm{Cr}, \mathrm{Se}$, and $\mathrm{U})$ than igneous phosphates [9-12]. Although sedimentary phosphates are characterized by a significantly higher content of: $\mathrm{Be}, \mathrm{Cd}, \mathrm{Cr}, \mathrm{Ni}$, Mo and $\mathrm{U}$, compared to igneous phosphates, the latter still contain a substantial amount of these heavy metals $[13,14]$. Apatite mining on the Khibiny apatitenepheline ore deposits in NW Russia has affected ground waters near the mines through elevated concentrations of total dissolved solids and metals [14]. These observations together with the fact that approximately one fifth of the world's marketable phosphate production is derived from igneous rocks $[13,15]$ make the study of igneous rock phosphate a necessity. Although there are numerous studies on heavy metals in sedimentary and igneous phosphates, there are a relatively limited number of references dealing with the actual minerals that host the heavy metals. The phosphates at Dorowa are mined from an alkaline ring complex that possesses structural, petrological, mineralo-

*Address correspondence to this author at the Department of Geology, University of Zimbabwe, P.O. Box MP167, Mt. Pleasant, Harare, Zimbabwe; Tel: 263712634164; Fax: 2634303557; E-mails: maideyimeck@yahoo.com or mabvira@science.uz.ac.zw gical and geochemical features similar to other igneous phosphate deposits known in the world. Therefore results from this study can be extended to these other deposits.

Though substantial work on the mineralogy of the Dorowa ring complex has been carried out [16-21], prior to this study there was no data available on those minerals potentially hosting heavy metals from this ring complex. Thus this work set out to determine the major minerals at Dorowa mine and identify those that have a potential of hosting metals and make the study a basis for applying to other phosphate deposits of igneous origin. The knowledge of metal host is vital as it gives an insight on fate of metals. The results from this study will be used to predict the longterm impacts of mining activities around Dorowa Mine, particularly with respect to the quality of drinking water. Around the study area (Dorowa), most villagers use the Save River as their primary drinking water source.

\section{GEOLOGY OF THE RING COMPLEX AND SAMPLING}

The study area is Dorowa Mine, situated in the catchment of the Save River, Zimbabwe (Fig. 1). The area is located in the Buhera District of Zimbabwe at $19^{\circ} 04^{\prime} \mathrm{S} ; 31^{\circ} 46^{\prime} \mathrm{E}$. The geology of the Dorowa alkaline ring complex was investigated in detail by [17] and [21].

The mine is exploiting a Mesozoic carbonatite that is associated with foyaite, ijolite and pulaskite [18]. The calcium carbonate plug forms a very small portion of the complex and the foyaites and ijolites have been extensively mineralized with phlogopite, vermiculite and apatite. The main rock being mined at Dorowa is fluoro-apatite $\left(\mathrm{Ca}_{5}\right.$ $\left(\mathrm{PO}_{4}\right)_{3}(\mathrm{OH}, \mathrm{F}, \mathrm{Cl})$ rock which comprises more than $50 \%$ of the apatite. Carbonate and hydroxyl apatite are also present 


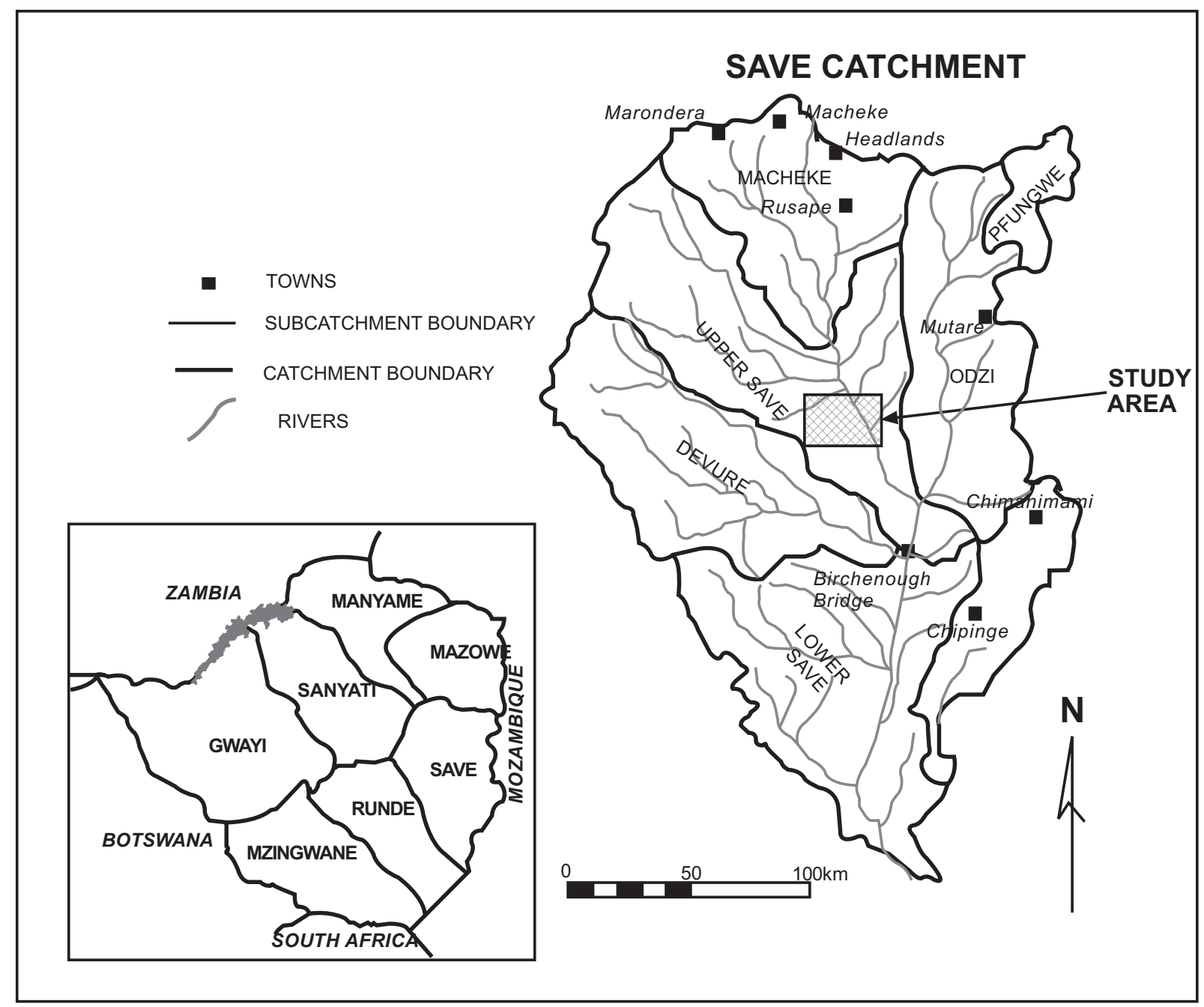

Fig. (1). Study area Dorowa in the Save Catchment of Zimbabwe.

[22]. Mining is concentrated in two main centres within the syenite fenite known as the North and South Pits. In the North Pit apatite occurs with vermiculite in the form of dykes, veins and stringers [17] whilst in the South Pit it occurs with pyroxene. Fig. (2) shows a sketch map of the geology of the Dorowa Complex.

The main rock types in the area are pyroxenites, igneous carbonatites, iron bearing rocks and alkaline syenites [18, 20]. These rocks are intersected by carbonates, feldspar veins and ultramafic dykes. The relationship between the different rock types is very complex. Nevertheless, during sampling an attempt was made to sample from all the major rocks types that could be visually distinguished. The following rock types were sampled; syenite, pyroxenite, apatite rock, carbonatite, magnetite rock and dolerite. Based on the mineralogy five syenites, three pyroxenites, two apatite bearing rocks, two dolerites, one carbonatite and one magnetite bearing rock were analyzed.

\section{Analytical Methods}

The rock samples were crushed and split into fractions by coning and quartering. The sample size was determined by the variability of the rock. In all cases it was ensured that the total sample for a rock was sufficient to properly characterize the rock described. The rock samples were ground and pulverized to pass through a $180 \mu \mathrm{m}$ sieve. To minimize contamination, an agate mortar and pestle was used for grinding and pulverizing the samples.

$\mathrm{X}$-ray diffraction was used to identify the major minerals present. The X-ray diffraction (XRD) patterns were recorded on un-oriented powder using an X'Pert Quantify Diffractometer with a Gonio Scan Axis operating at $30 \mathrm{~mA}$ and $40 \mathrm{kV}$ using $\mathrm{CuK} \alpha$ radiation. The samples were scanned in the range, $3-80^{\circ}, 2 \theta$ using a continuous scan step size of $0.02^{\circ}$ $2 \theta$ and scan step time of $0.5 \mathrm{~s}$. The method used identifies all phases greater than $2 \%$ in the sample. The phases were indexed using Diffrac-AT software linked to a JCPDS database. XRD scans were matched, based on the so-called "figure-of-merit" with a standard mineral database [ICDD PDF2 (2002)]. All phases indicated to be present in a sample were evaluated by verifying peak by peak to see if there was a close match with the powder diffraction file.

ICP- MS was used to analyze for the metals in the rock samples. The metals analyzed for in this study are those that are of concern to plant, animal and human health. [23] prioritized the following elements as the most toxic from the 


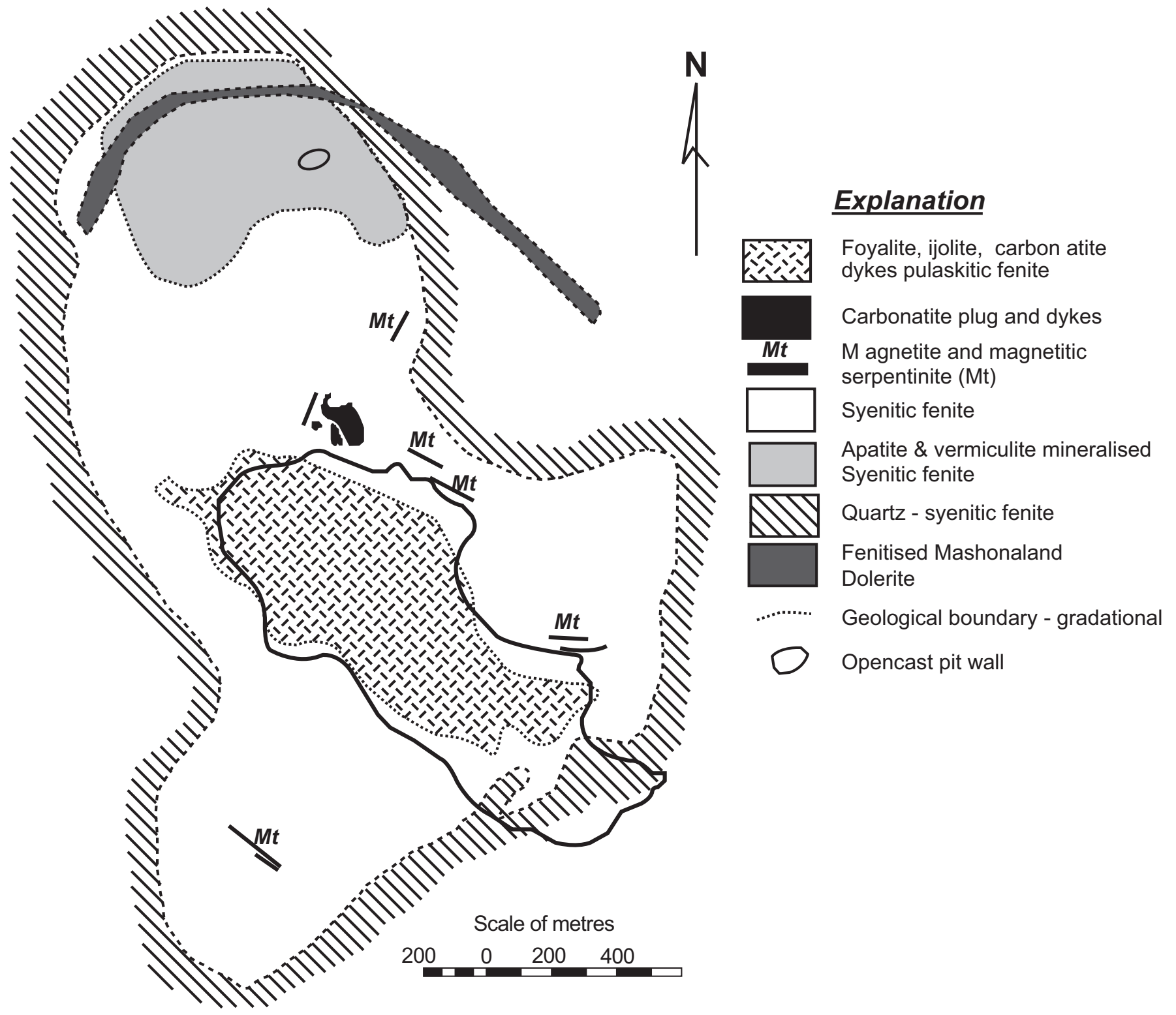

Fig. (2). Sketch Geology map of the Dorowa Carbonatite after [21].

standpoint of potential hazard to plants and human healthy: arsenic (As), beryllium (Be), antimony ( $\mathrm{Sb})$, cadmium $(\mathrm{Cd})$, chromium $(\mathrm{Cr})$, copper $(\mathrm{Cu})$, lead $(\mathrm{Pb})$, mercury $(\mathrm{Hg})$, nickel (Ni), selenium (Se), silver (Ag), and zinc ( $\mathrm{Zn})$. [24] classified metals according to toxicity and availability into three categories namely: non critical; toxic but insoluble or very rare; and very toxic and relatively accessible. Their very toxic and relatively accessible category contained beryllium $(\mathrm{Be})$, cobalt $(\mathrm{Co})$, nickel $(\mathrm{Ni})$, zinc $(\mathrm{Zn})$, tin $(\mathrm{Sn})$, arsenic (As), selenium $(\mathrm{Se})$, tellurium $(\mathrm{Te})$, palladium $(\mathrm{Pd})$, silver $(\mathrm{Ag})$, cadmium $(\mathrm{Cd})$, platinum $(\mathrm{Pt})$, gold $(\mathrm{Au})$, mercury $(\mathrm{Hg})$, thallium $(\mathrm{To})$, lead $(\mathrm{Pb})$, antimony $(\mathrm{Sb})$ and bismuth (Bi) in specific forms. The elements common in the two classifications are $\mathrm{Ag}, \mathrm{As}, \mathrm{Be}, \mathrm{Cd}, \mathrm{Co}, \mathrm{Cu}, \mathrm{Pb}, \mathrm{Hg}, \mathrm{Ni}, \mathrm{Sb}$, $\mathrm{Se}$, and $\mathrm{Zn}$. Thus these metals were analyzed for in this study. $\mathrm{Hg}$ was not analyzed for due to unavailability of the appropriate equipment.

\section{RESULTS}

Phases detected by the XRD analysis in the 14 rock samples are summarized in Table 1. A summary of minerals found in the ring complex are given in Table $\mathbf{2}$ which also lists the observed chemical formula, and the group to which the observed mineral belongs. The major minerals at Dorowa are feldspars, pyroxenes, apatite, magnetite and calcite. Feldspars and pyroxene are present in 11 out of 14 samples. In 8 of the samples apatite minerals were found. In three samples, small peaks corresponding to clays (which are probably alteration products of the magmatic minerals) were observed. Though the clay mineral could be identified as montmorillonite in one of the rocks (Meck 2), the peaks in the other two rocks (Meck 9 and Meck 12) were insufficient to allow determination of the mineral present. The XRD results show the presence of fluor-apatite and hydroxyl apatite in the Dorowa Complex. These observations compare 
Table 1. Minerals Picked Up by XRD in the Different Rock Samples

\begin{tabular}{|c|c|c|}
\hline Sample Name & Minerals Picked by XRD & Rock Name \\
\hline \hline Meck1 & calcium carbonate, fluoro-apatite & Syenite \\
\hline Meck2 & fluorapatite, Ce-rich, augite, albite, montmorillonite & Dolerite \\
\hline Meck3 & Albite intermediate, , sodium tecto-alumosilicate, diopside, apatite & Pyroxenite \\
\hline Meck4 & iron diiron(III) oxide, magnetite low, syn, iron III hydrogen oxide, magnetite & Magnetitite \\
\hline Meck5 & Albite, ordered, augite & Syenite \\
\hline Meck 6 & Diopside, aluminian, syn, augite, albite, flourapatite, bytownite, enstatite & Pyroxenite \\
\hline Meck 7 & Hydroxyl apatite, syn, iron diiron(III) oxide & Phosphate rock \\
\hline Meck 8 & Augite Hydroxyl apatite, syn Albite, ordered & Pyroxenite \\
\hline Meck 9 & Calcite, Montmorillonite-15A & Carbonatite \\
\hline Meck 10 & Diopside, aluminian, Hydroxyl apatite, Albite, ordered & Dolorite \\
\hline Meck 11 & Albite, calcian, augite, lazurite, nepheline & Syenite \\
\hline Meck 12 & Albite, ordered, Anorthoclase, disordered, Montmorillonite & Syenite \\
\hline Meck 13 & Albite, calcian, ordered Orthoclase, Augite, aluminian & Syenite \\
\hline Meck 14 & Hydroxyl apatite, syn Actinolite, Magnetite, syn, $\alpha$-Si O ${ }_{2}$, quartz HP & Phosphate Rock \\
\hline
\end{tabular}

Table 2. Major Minerals in the Dorowa Ring Complex

\begin{tabular}{|c|c|c|c|c|}
\hline Mineral/ Compound & Group/Family & General Formula & Empirical Formula & Minerals Observed in this Study \\
\hline Calcium carbonate & Carbonate & $\mathrm{CaCO}_{3}$ & $\mathrm{CaCO}_{3}$ & $\mathrm{CaCO}_{3}$ \\
\hline Fluorapatite & Phosphate & $\mathrm{Ca}_{5}\left(\mathrm{PO}_{4}\right)_{3} \mathrm{~F}$ & $\mathrm{Ca}_{5}\left(\mathrm{PO}_{4}\right)_{3} \mathrm{~F}$ & $\begin{array}{c}\mathrm{Ca}_{9.653} \mathrm{Ce}_{0.327} \mathrm{Na}_{0.02}\left(\mathrm{SiO}_{.32} \mathrm{P}_{5.68}\right. \\
\left.\mathrm{O}_{24}\right) \mathrm{F}_{1.48}(\mathrm{O} \mathrm{H})_{0.52} \\
\mathrm{Ca}_{5}\left(\mathrm{PO}_{4}\right)_{3} \mathrm{~F}_{.94} \mathrm{Cl}_{.1}\end{array}$ \\
\hline Albite & Silicate & $\mathrm{NaAlSi}_{3} \mathrm{O}_{8}$ & $\mathrm{Na}_{0.95} \mathrm{Ca}_{0.05} \mathrm{Al}_{1.05} \mathrm{Si}_{2.95} \mathrm{O}_{8}$ & $\begin{array}{c}\left(\mathrm{Na}_{0.98} \mathrm{Ca}_{0.02}\right)\left(\mathrm{Al}_{1.02} \mathrm{Si}_{2.98} \mathrm{O}_{8}\right) \\
\mathrm{Na} \mathrm{Al} 1.08 \mathrm{Si} 2.92 \mathrm{O} 8\end{array}$ \\
\hline Diopside & Silicate & $\mathrm{CaMgSi}_{2} \mathrm{O}_{6}$ & $\mathrm{CaMg}\left(\mathrm{Si}_{2} \mathrm{O}_{6}\right)$ & $\begin{array}{c}\mathrm{Ca} \mathrm{Mg}\left(\mathrm{Si} \mathrm{O}_{3}\right)_{2} \\
\mathrm{Ca}(\mathrm{Mg}, \mathrm{Al})(\mathrm{Si}, \mathrm{Al})_{2} \mathrm{O}_{6}\end{array}$ \\
\hline Apatite & Phosphate & $\mathrm{Ca}_{5}\left(\mathrm{PO}_{4}\right)_{3}(\mathrm{OH}, \mathrm{F}, \mathrm{Cl})$ & $\mathrm{Ca}_{5}\left(\mathrm{PO}_{4}\right)_{3}(\mathrm{OH})_{0.3333} \mathrm{~F}_{0.3333} \mathrm{Cl}_{0.3333}$ & $\mathrm{Ca}_{5}(\mathrm{~F}, \mathrm{Cl}) \mathrm{P}_{3} \mathrm{O}_{12}$ \\
\hline Hydroxyl apatite & Phosphate & $\mathrm{Ca}_{5}\left(\mathrm{PO}_{4}\right)_{3}(\mathrm{OH})$ & $\mathrm{Ca}_{5}\left(\mathrm{PO}_{4}\right)_{3}(\mathrm{OH})$ & $\mathrm{Ca}_{9.42} \mathrm{Sr}_{0.18} \mathrm{H}_{0.4}\left(\mathrm{PO}_{4}\right)_{6}(\mathrm{OH})_{1.60}$ \\
\hline Montmorillonite-15A & Clay & $\begin{array}{c}(\mathrm{Na}, \mathrm{Ca})_{0,3}(\mathrm{Al}, \mathrm{Mg})_{2} \mathrm{Si}_{4} \mathrm{O}_{10} \\
(\mathrm{OH})_{2 \cdot n}\left(\mathrm{H}_{2} \mathrm{O}\right)\end{array}$ & $\mathrm{Na}_{0.2} \mathrm{Ca}_{0.1} \mathrm{Al}_{2} \mathrm{Si}_{4} \mathrm{O}_{10}(\mathrm{OH})_{2}\left(\mathrm{H}_{2} \mathrm{O}\right)_{10}$ & $\mathrm{Ca}_{0.2}(\mathrm{Al}, \mathrm{Mg})_{2} \mathrm{Si}_{4} \mathrm{O}_{10}(\mathrm{OH})_{2 \cdot 4} \mathrm{H}_{2} \mathrm{O}$ \\
\hline Lazurite & Silicate & $\mathrm{Na}_{3} \mathrm{Ca}\left(\mathrm{Al}_{3} \mathrm{Si}_{3} \mathrm{O}_{12}\right) \mathrm{S}$ & $\mathrm{Na}_{3} \mathrm{CaAl}_{3} \mathrm{Si}_{3} \mathrm{O}_{12} \mathrm{~S}$ & $\mathrm{Na}_{3} \mathrm{CaAl}_{3} \mathrm{Si}_{3} \mathrm{O}_{12} \mathrm{~S}$ \\
\hline Anorthoclase & Silicate & $(\mathrm{Na}, \mathrm{K}) \mathrm{AlSi} 3 \mathrm{O} 8$ & $\mathrm{Na}_{0.75} \mathrm{~K}_{0.25} \mathrm{AlSi}_{3} \mathrm{O}_{8}$ & $(\mathrm{Na}, \mathrm{K})\left(\mathrm{Si}_{3} \mathrm{Al}\right) \mathrm{O}_{8}$ \\
\hline Nepheline & Silicate & $(\mathrm{Na}, \mathrm{K}) \mathrm{AlSiO} 4$ & $\mathrm{Na}_{0.75} \mathrm{~K}_{0.25} \mathrm{Al}\left(\mathrm{SiO}_{4}\right)$ & $\mathrm{Na}_{3} \mathrm{KAl}_{4} \mathrm{Si}_{4} \mathrm{O}_{16}$ \\
\hline Actinolite & Silicate & $\mathrm{Ca}_{2}\left(\mathrm{Mg}, \mathrm{Fe}^{++}\right)_{5} \mathrm{Si}_{8} \mathrm{O}_{22}(\mathrm{OH})_{2}$ & $\mathrm{Ca}_{2} \mathrm{Mg}_{3} \mathrm{Si}_{8} \mathrm{O}_{22}(\mathrm{OH})_{2} \mathrm{Fe}^{2+}{ }_{2}$ & $\mathrm{Ca}\left(\mathrm{Mg}, \mathrm{Fe}^{+2}\right) \mathrm{Si}_{2} \mathrm{O}_{6 \cdot 2}(\mathrm{Mg}, \mathrm{Fe}) \mathrm{SiO}_{3}$ \\
\hline Quartz & Silicate & $\mathrm{SiO}_{2}$ & $\mathrm{SiO}_{2}$ & á-Si $\mathrm{O}_{2}$ \\
\hline $\begin{array}{l}\text { Iron(III) hydrogen } \\
\text { Oxide }\end{array}$ & Oxide & & & $\mathrm{Fe}_{1.98} \mathrm{H}_{0.06} \mathrm{O}_{3}$ \\
\hline
\end{tabular}

well with the work done by previous researchers $[16-18,20]$ and observations elsewhere in the world which shows that fluor-apatite is the dominant apatite in crustal rocks but occurs with hydroxyl apatite in most cases [15].

The ICP-MS results shows that most rocks at Dorowa are associated with the metals $\mathrm{Ag}, \mathrm{As}, \mathrm{Be}, \mathrm{Cd}, \mathrm{Co}, \mathrm{Cu}, \mathrm{Pb}, \mathrm{Ni}$,
$\mathrm{Sb}, \mathrm{Se}, \mathrm{Zn}$. Fig. (3) shows the metals associated with the different rocks analyzed. The data shows that the rocks Meck 3, Meck 4, Meck 9 have the highest metal levels. Analysis of the XRD results in table 1 show that these rocks contain magnetite, calcite and apatite. Meck 1, Meck 2, Meck 5 and Meck 10 have the lowest metal levels. These rocks are either 


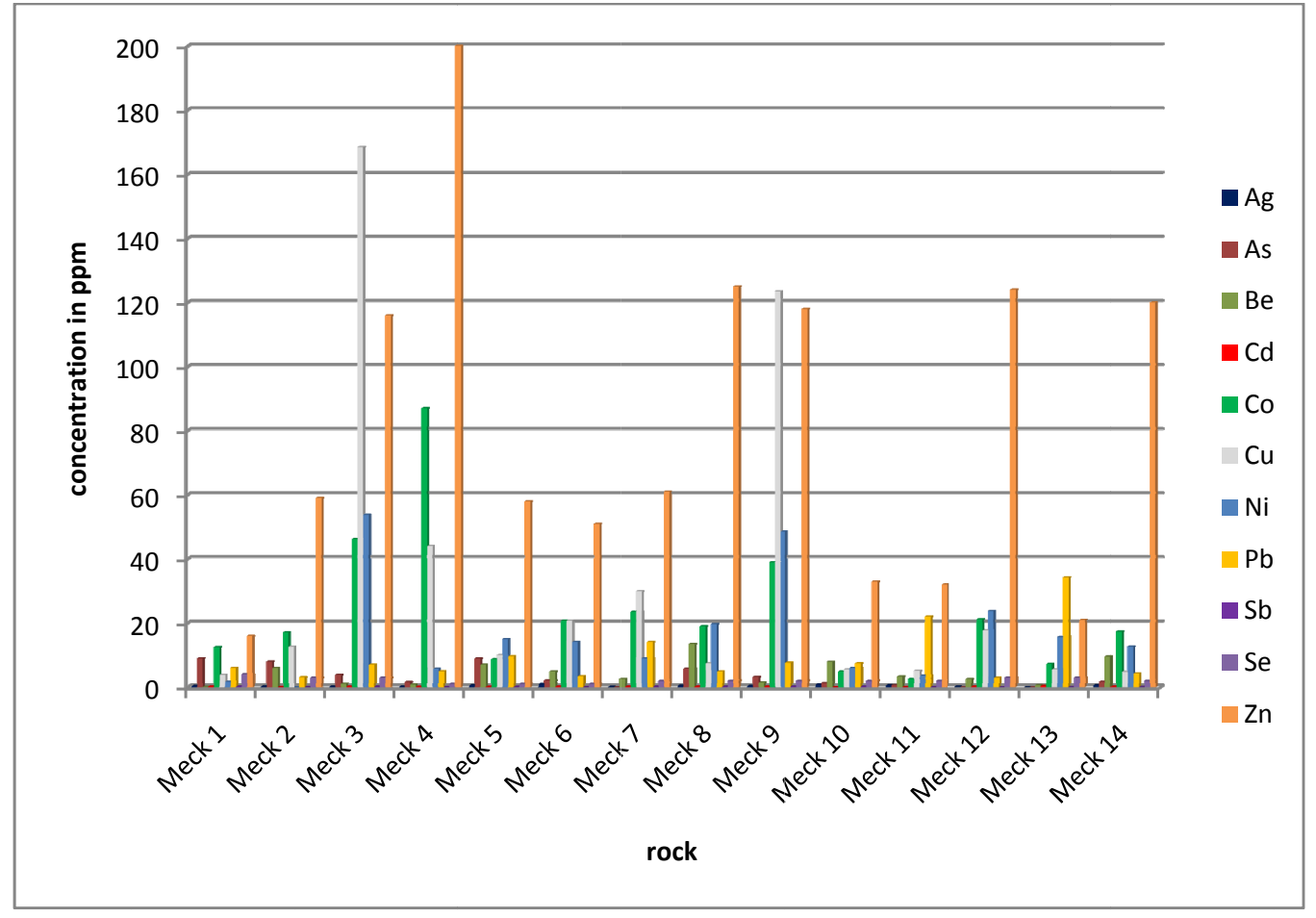

Fig. (3). Metal levels in the different rocks around Dorowa.

dolerites or syenites with very low amounts of apatite minerals. The rocks with flouro apatite (Meck, 1, Meck2, and Meck6) have generally lower metal levels than those with hydroxyl apatite (Meck 7, Meck 8 and Meck 14).

A comparison of the metal levels in the rock phosphate at Dorowa obtained in this study with rock phosphates from other places in the world shows that the levels obtained in this study are within the average levels of similar rocks. Fig.
(4) gives a graphical representation of the levels of metals obtained in this study alongside average heavy metal concentrations in phosphate rock (PR) deposits cited by [4].

\section{DISCUSSION}

Based on the evidence presented from the XRD scans and the ICP-MS results a good case can be made that the

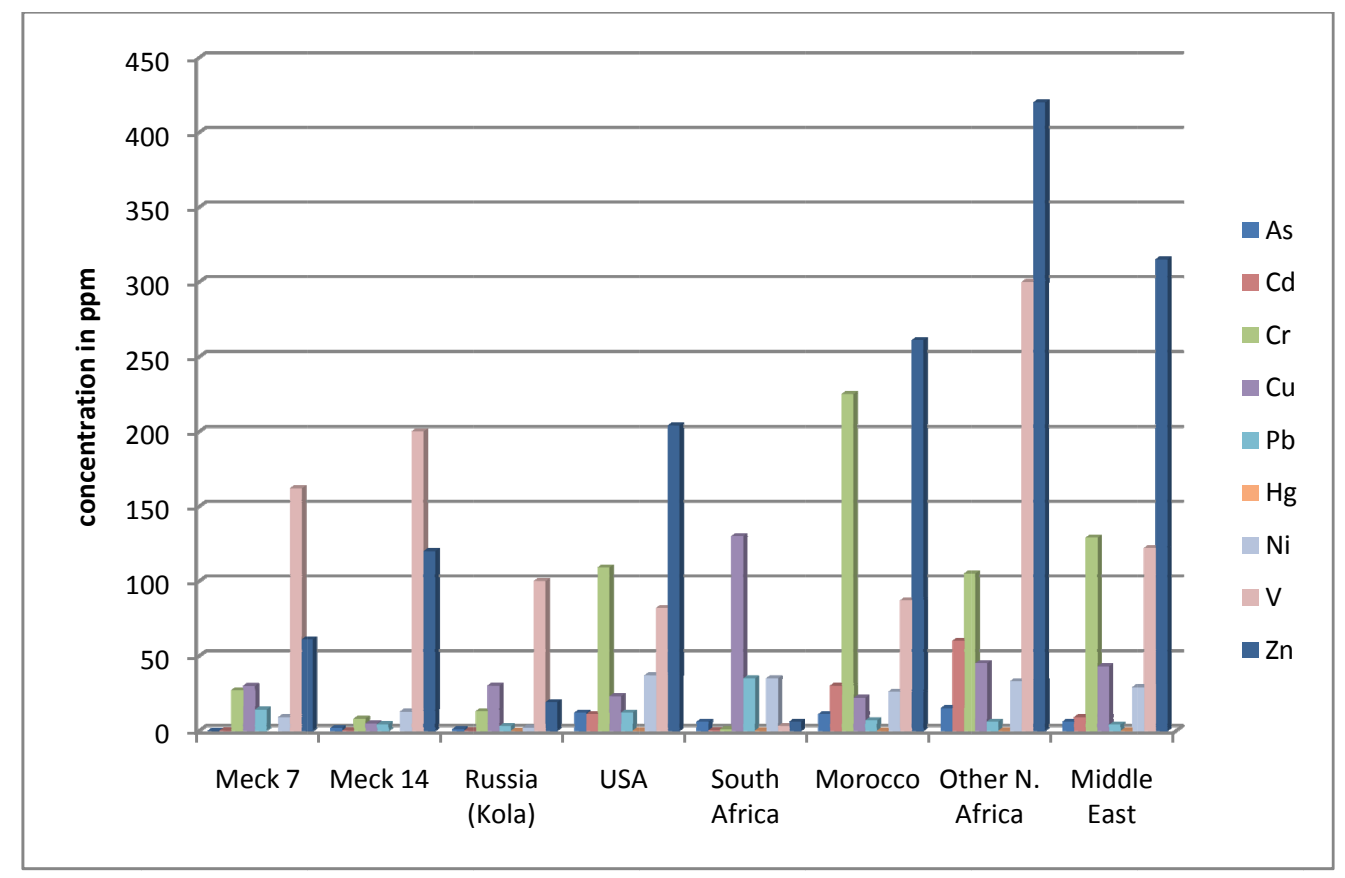

Fig. (4). Metals levels in the two rock phosphates from the study area alongside average heavy metal concentrations in phosphate rock (PR) deposits cited by [4] as data obtained by Kongshaug et al., 1992. 
culprit minerals are magnetite, calcite and apatite. The rocks with these minerals have higher metal content. Fig. (5) shows the total metal content for the rocks in the ring complex.

The carbonatite and apatite bearing rocks (Meck 3, Meck 4, Meck 9) have higher levels of metals compared to the other rocks. Analysis of the phases present in the rocks shows that the carbonatite Meck 9 contains lower total metal content when compared to Meck 3 and Meck 4 which are apatite bearing rocks. This data is therefore implying that the minerals with higher potential of hosting metals in the Dorowa complex are apatite and calcite. Both results in XRD and ICP-MS results concur that calcite and apatite are likely to host metals. The XRD data presented in Table 2 shows that the various apatites found in the study area have a site that is hosting trace elements further confirming that these apatites have a potential for hosting metals. The data is also indicating that metal hosting is lower in calcite minerals and higher in apatite minerals.

The crystal-chemistry of the two minerals (calcites and apatites) were scrutinized to explain metal hosting in these minerals making use of literature by [23-40] that summarizes the mechanisms of element incorporation in carbonates, phosphates, and silicates. The literature provides the fundamental constraints on reactions such as sorption, coprecipitation, crystal growth, and dissolution; thus dictating the elements hosted.

\section{Phosphates Substitution}

Apatite is more likely to host the metals because its structure is characterized by various substitutions (e.g. $\mathrm{Sr}^{6+}$ or $\mathrm{Ba}^{6+}$ for $\mathrm{Ca}^{2+} ;\left(\mathrm{SiO}_{4}\right){ }^{4-}$ for $\left(\mathrm{PO}_{4}\right)^{6-}$ and $\mathrm{Cl}^{-}$or $\mathrm{F}^{-}$for $\left.(\mathrm{OH})\right)$ without a significant alteration to its basic structure. Thus it can bind many toxic metals into stable mineral structures. There are two distinct $\mathrm{Ca}$ sites in the apatite structure i.e. the $\mathrm{Ca} 1$ site which is coordinated by nine $\mathrm{O}$ atoms and the $\mathrm{Ca} 2$ site which is coordinated by six $\mathrm{O}$ atoms. The size and geometry of the $\mathrm{Ca} 2$ site varies, depending on the column anion. $\mathrm{Ca}$ may be substituted by $\mathrm{K}, \mathrm{Na}, \mathrm{Mn}, \mathrm{Ni}, \mathrm{Cu}, \mathrm{Co}, \mathrm{Zn}$, $\mathrm{Sr}, \mathrm{Ba}, \mathrm{Pb}, \mathrm{Cd}, \mathrm{Sn}, \mathrm{Y}$, and Rare Earth Elements (REE). Substitution of trivalent cations such as REE for $\mathrm{Ca} 2$ has been shown to be coupled with substitutions of $\mathrm{Na}^{+}$or $\mathrm{Ca}^{2+}$ $[41,42]$. The structure also allows elements such as arsenic and chromium to be substituted by exchanging with the phosphate ions. Substitution of metals in apatite and the resultant diverse compositions are described by [43-50]. Size limit related the anion and cation radius for phosphates are elaborated by [51-53].

\section{Carbonate Substitution}

Several studies have been carried out to consider elemental substitution within calcite structure carbonates [54-59] and conclude that substitution is controlled primarily by gross features of the crystal structure. The crystal structure of many carbonate minerals reflects the trigonal symmetry of the carbonate ion, which is composed of a carbon atom centrally located in an equilateral triangle of oxygen atoms [60]. According to [53] the range of radius ratio that can substitute in the structure is $0.155-0.225 \AA$. Alkaline earth elements in carbonates can be substituted by the 3-d transition metals [61]. The carbonate anion group usually occurs in combination with calcium, sodium, uranium, iron, aluminum, manganese, barium, zinc, copper, lead, or the rare-earth elements [60]. Relatively common carbonate minerals serve as metal ores: siderite, for iron; rhodochrosite, for manganese; strontianite, for strontium; smithsonite, for zinc; witherite, for barium; and cerussite, for lead.

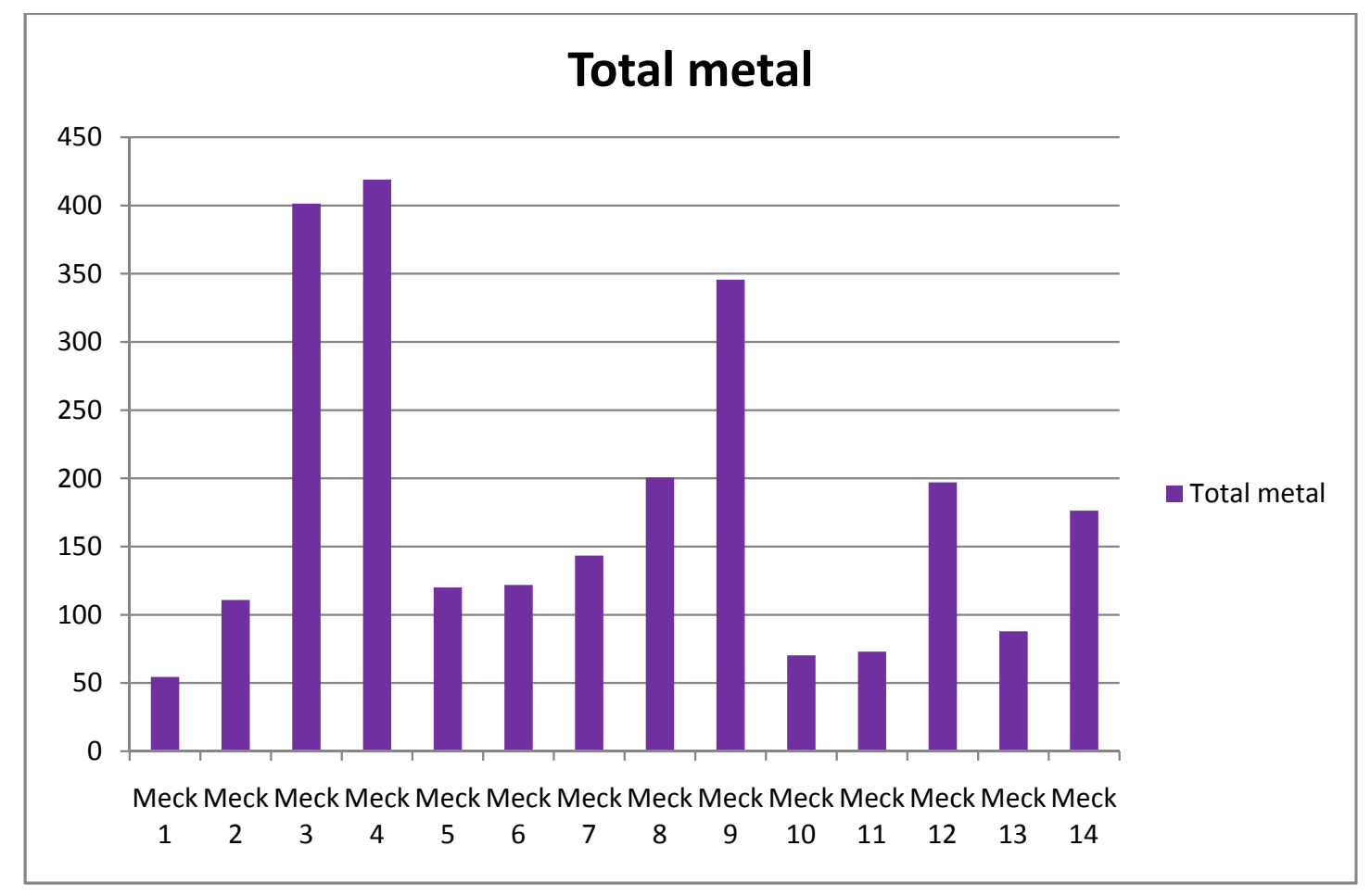

Fig. (5). Total metal content in the different rock types at Dorowa. 
Substitution depends on chemical composition, crystal structure, pressure and temperature [34, 62]. Substitution of the metal ions therefore occurs in the $\mathrm{Ca}$ site $[62,63]$ summarize the comparative compressibility's of calcitestructure carbonates and notes that relaxation around an "impurity" ion is localized, and the corner-sharing structural topology of calcite facilitates the observed wide spectrum of impurity substitution. Though the calcite-structure carbonates represent a mineral group that is structurally different from oxides and silicates, the Mg-Fe substitution in calcitestructure is similar in magnitude to that in silicate spinels which means the absolute difference is typically no more than a few percent for complete substitution [64].

Co-precipitation experiments from aqueous solution at room temperature reveal that divalent $\mathrm{Co}, \mathrm{Zn}, \mathrm{Cd}$, and $\mathrm{Ba}$ exhibit different preferences for incorporation among multiple surface sites present on the calcite face during spiral growth [65]. Experimental work on the co- precipitation of divalent $\mathrm{Co}, \mathrm{Zn}, \mathrm{Mn}, \mathrm{Fe}, \mathrm{Cd}, \mathrm{Sr}, \mathrm{Pb}$, and $\mathrm{Ba}$ with $\mathrm{Ca}$ in calcite has shown strongly selective uptake in structurally distinct surface sites on the calcite. Despite distinct surfacesite preferences and uptake patterns varying in magnitude by more than a factor of ten, bulk coordination differs only minimally [66] have also shown that trapping can also lead to metal hosting in minerals when he showed a calcite deposit trapping traces of $\mathrm{Pb}, \mathrm{Zn}$ and $\mathrm{Cd}[(\mathrm{Ca}, \mathrm{nPb}, \mathrm{nZn}$, $\mathrm{nCd}) \mathrm{CO}_{3}$ during carbonation. The major carbonate in the study area is calcite thus significant trapping and substitution of potential pollutants is possible.

This study has established the minerals potentially hosting toxic metals. Chemical data provided has shown that the levels of metals are higher in the rocks that contain calcite and apatite. The discussion has elaborated mechanisms by which the metals are hosted in the calcite and apatite minerals.

\section{CONCLUSION}

This paper presents an insight into the minerals that are likely to host the metals in the study area. It is an important step needed prior to modeling because it enables the determination of the suppositions needed for the model, as it provides evidence concerning the minerals that control potential pollutants. The carbonates and phosphates have been identified as the potential pollutant host minerals. Highgrade quality rock phosphate deposits are being depleted worldwide due to increased agricultural activities, so more and more mining companies are turning to lower quality sources and more to igneous rock phosphates. Because most rock phosphates of igneous origin are associated with several minerals, use of them as a source for phosphate-fertilizers increase the use of minerals that may contain heavy metals. The study has shown an increase in conductivity, iron content, manganese content, nitrates and hardness downstream of the study area. Thus deductions from this study and similar studies can be used to quickly pinpoint the minerals that host the pollutants and therefore take the necessary precautions. It should also be noted that as much as two thirds of the world's known phosphate resources are composed of carbonate rich phosphate rock therefore exploitation of these deposits, provides a potential for contamina- tion of the areas surrounding the mines and also areas where they are used by increasing heavy metal levels.

\section{ACKNOWLEDGEMENTS}

The work is being carried out as part of a regional study of Sustainable Integrated Management of Arid and SemiArid Region of southern Africa (SIMDAS) funded by the United Nation Education and Scientific Cooperation (UNESCO) and developed for the SADC region. The authors acknowledge UNESCO for funding the project. We also acknowledge the University of Zimbabwe and the University of Botswana for co-ordinating the project.

\section{REFERENCES}

[1] Appleton, J.D. Phosphate resources for sustainable development in Sub Saharan Africa. Brit. Geologic. Surv. Rep., CR/02/121/N., 2002, pp. 134.

[2] Mortvedt, J. J.; Sikora, F. J. Heavy metal, radionuclides, and fluorides in phosphorus fertilizers. In: Future directions for agricultural phosphorus research, Sikora, F.J., Ed.; TVA Bull Y-224. Muscle Shoals: USA, 1992, pp. 69-73.

[3] Kpomblekou, K.; Tabatabai, M.A. Metal contents of phosphate rocks, Commum. Soil Sci. Plant Anal., 1994, 25(17, 18), 28712882 .

[4] Mortvedt, J.J; Beaton, J.D. Heavy metal and radionuclide contaminants in phosphate fertilizers. In: Phosphorus in the global environment: transfers, cycles and management, Tiessen, H., Ed.; SCOPE 54, chapter 6. 1995. http://www.icsuscope.org/ downloadpubs/scope 54/mortvedt.htm. (accesses Oct 14, 2008).

[5] Schnug, E.; Hanklaus, S.; Schnier, C.; Scholten, C. Issues of natural radioactivity in phosphates. Commun. Soil Sci. Plant Anal., 1996, 27(3, 4), 829-841.

[6] Mortvedt, J.J. Heavy metal contaminants in inorganic and organic fertilizers. Fert. Res., 1996, 43, 55-61.

[7] Schnug, E.; Haneklaus, S.; Rogasik, J.; Gassner, A. In: Utilization of fertiliser $\mathrm{P}$ with special regard to organic farming, Proceedings of the 14th International Symposium of Fertilizers, June 22-25, 2003, Debrecen, Braunschweig: Schnug, E., Nagy, J., Nemeth, T., Kovacs, Z., Dövenyi-Nagy, T., Eds.; Fert in cont with res management in agric. 2003, pp. 11-29.

[8] Makweba, M.M.; Holm, E. The natural radioactivity of the rock phosphates, phosphatic products and their environmental implications. Sci. Total Environ, 1993, 133, 99-110.

[9] Kratz, S.; Schnug, E. In: Rock phosphates and P-fertilizers as sources of $U$ contamination in agricultural soils. Merkel, B.J.; Hasche-Berger, A., Eds.; U in the environment. Heidelberg: Berlin. Springer, 2006, pp 57-68.

[10] Kratz, S.; Schnug, E. Schwermetalle in P-Düngern. Rec $A d v$ Agricul Chem (Special Issue)., 2005, 286, 37-45.

[11] Tufail, M.; Akhtar, N.; Wagas, M. Radioactive rock phosphate: The feed stock of phosphate fertilizers used in Pakistan. Health Phys., 2006, 90 (4), 361-370.

[12] Van Kauwenbergh, S.J. In: Cadmium and other Minor elements in world resources of phosphate rock. Proceed of the Fert Soc., 1997, No. 400, London.

[13] Sattouf, M.; Kratz, S.; Diemer, K.; Rienitz, O.; Fleckenstein, J.; Schiel, D.; Schnug, E. Identifying the origin of rock phosphates and phosphorus fertilizers through high precision measurement of the strontium isotopes 87Sr and 86Sr. Landbauforschung, 2007, 57 (1), $1-11$.

[14] Malinovsky, D.; Rodushkin, I.; Moiseenko, T.; O* hlander, B. Aqueous transport and fate of pollutants in mining area: a case study of Khibiny apatite-nepheline mines, the Kola Peninsula. Rus Environ Geol., 2002, 43, 72-187.

[15] Notholt, A. J. G.; Sheldon, R. P.; Davison, D.F., Eds.; Phosp depos of the world. Vol. 2: Phosphate rock resources Cambridge University Press Cambridge, UK 1989, pp. 80-100.

[16] Mennel, F.P. Ring structures with Carbonate Cores in Southern Rhodesia. Geological Magazine, 1946, 83 (3), 137-140. 
[17] Johnson, R.L. The geology of the dorowa and shawa carbonatite complexes Southern Rhodesia. Transact. Proceed. Geol. Soc. South Africa, 1961, 64, 101-146.

[18] Barber, B. Phosphate resources of Zimbabwe. Fert. Resou., 1991, 30, 247-278.

[19] Walsh, K.L.; Siegfried, P. Hall; R.P.; Hughes, D.J. Tectonic implications of four recently discovered carbonatites along the Zambezi escarpment fault, northern Zimbabwe. J. Afr. Health Sci., 2001, 32, 36-37.

[20] Fernandes, T.R.C. In: Dorowa and Shawa: late Palaeozoic to Mesozoic carbonatite complexes in Zimbabwe. Notholt, A.J.G.; Sheldon, R.P.; Davison, D.F., Eds.; Phosphate deposits of the world: Phosp. rock resou. Cambridge University Press, Cambridge: UK, 1989, Vol. 2, pp. 176-178.

[21] Lauderdale, J.N. The Geology of the country around Dorowa and Shawa, Buhera district. Zim. Geol. Surv. Bull. 95., Residual effects of novel phosphate.

[22] Fernandes, T.R.C. Electron microscopy applied to the beneficiation of apatite ores of igneous origin. Transact. Geol. Soc. S. Afr., 1978, $81,249-253$

[23] McBride, M.B. Environ. Chem. Soils., Oxford University Press: New York, 1994.

[24] Dallas, H.F.; Day, J.A. The effect of water quality variables on Riverine ecosystems: a review. Fresh water research unit. Wat. Res. Comm. Rep. TT61/93, University of Cape Town: S.A. 1993.

[25] Kersten, M.; Moor, H.C.; Johnson; C.A. Speciation of trace metals in leachate from a MSWI bottom ash landfill. Appl. Geochem., 1997, 12, 675-683.

[26] Feallman, A.M. Leaching of chromium and barium from steel slag in laboratory and field tests: a solubility controlled process? Waste Manage., 2000, 20, 149-154.

[27] Crannell, B.S.; Eighmy, T.T.; James, E.; Krzanowski, J.; Eusden, Jr. D.; Shaw, E.L.; Francis, C.A. Heavy metal stabilization in municipal solid waste combustion bottom ash using soluble phosphate. Waste Manage., 2000, 20, 135-148.

[28] Freyssinet, P.H.; Piantone, P.; Azaroual, M.; Itard, Y.; ClozelLeloup, B.; Guyonnet, D. Chemical changes and leachate mass balance of municipal solid waste bottom ash submitted to weathering. Waste Manage., 2002, 22, 159-172.

[29] Piantone, P.; Bodnana, F.; Chatelet-Snidarob, L. Mineralogical study of Major mineral phases from weathered MSWI bottom ash: implications for the modeling and trapping of heavy metals. Appl. Geochem., 2004, 19, 1891-1904.

[30] Goldschmidt, V.M. The principles of distribution of chemical elements in minerals and rocks. J. Chem. Soc. Lond., 1937, 1, 655673.

[31] Ringwood, A.E. The principles governing trace element distribution during crystallization. The influence of electronegativity. Geochimic. Cosmochimic. Acta., 1955, 7, 189-202.

[32] Burns, R.G. Mineral. Applicat. Cryst. Fiel. Theo., Cambridge University Press, Cambridge: UK, 1970, pp. 144-174.

[33] Burton, J.A.; Prim, R.C.; Slichter, W.P. The distribution of solute in crystals grown from the melt. I- Theoretical. J. Chemic. Phys., 1953, 21, 1987- 1991 .

[34] Zhang, J.; Reeder; R.J. Comparative compressibilities of calcitestructure Carbonates: deviations from empirical relations. $\mathrm{Am}$. Mineral., 1999, 84, 861-870.

[35] Nakamura, Y. Origin of sector zoning in igneous clinopyroxenes. Am. Mineral., 1973, 58, 986-990.

[36] Dowty, E. Crystal structure and crystal growth. II. Sector zoning in minerals. Am. Mineral., 1976, 61, 460-469.

[37] Dowty, E. The importance of adsorption in igneous partitioning of trace elements. Geochim. Cosmochim. Acta., 1977, 41, 1643-1646.

[38] Reeder, R.J.; Grams, J.C. Sector zoning in calcite cement crystals: Implications for trace element distributions in carbonates. Geochim. Cosmochim. Acta., 1987, 51, 187-194.

[39] Paquette, J.; Reeder, R.J. A new type of compositional zoning in calcite: Insights into crystal-growth mechanisms. Geology, 1990, 18, 1244-1247.

[40] Reeder, R.J.; Lamble, G.M.; Northrup, P.A. XAFS study of the coordination and local relaxation around $\mathrm{Co}^{2+}, \mathrm{Zn}^{2+}, \mathrm{Pb}^{2+}$ and $\mathrm{Ba}^{2+}$ trace elements in calcite. Am. Mineral., 1999, 84, 1049-1060.

[41] Ronsbo, J.G. Coupled substitutions involving REEs and $\mathrm{Na}$ and $\mathrm{Si}$ in apatites in alkaline rocks from the Ilimaussaq intrusion, South
Greenland, and the petrological implications. Am. Mineral., 1989, 74, 896-901.

[42] Hughes, J.M.; Cameron, M.; Mariano, A.N. Rare-earth-element ordering and structural variations in natural rare-earth-bearing apatites. Am. Mineral., 1991, 76, 1165-1173.

[43] McConnell, D. Apatite: its crystal chemistry, mineralogy, utilization and geologic and biologic occurrences. Springer-Verlag, New York, 1973, pp. 22-31.

[44] Kreidler, E.R.; Hummel, F.A. The crystal chemistry of apatite: structure fields of fluor- and chlorapatite. Am. Mineral., 1970, 55, 170-184

[45] Roy, D.M.; Drafall, L.E.; Roy, R. Crystal chemistry, crystal growth and phase equilibria of apatite. Phase Diag., 1978, 5, 185-239.

[46] Fleet, M.E.; Pan, Y. Crystal chemistry of rare earth elements in fluorapatite and some calcsilicates. Eur. J. Mineral., 1995, 7, 591605.

[47] Fleet, M.E.; Pan, Y. Site preference of rare earth elements in fluorapatite. Am. Mineral., 1995, 80, 329-335.

[48] Gutowska, I.; Machoy, Z.; Machalinski, B. The role of bivalent metals in hydroxyapatite structures as revealed by molecular modeling with the Hyper Chem software Wiley, 2005 http:// www.interscience.wiley.com. DOI: 10.1002/jbm.a.30511 (accessed April 17, 2008).

[49] Moriguchi, T.; Nakagawa, S.; Kaji, F. Reaction of Ca-deficient Hydroxyapatite with heavy metal ions along with metal substitution. Phosp. Res. Bull., 2008, 22, 54-60.

[50] Peld, M.; Tonsuaadu, K.; Bender, V. Sorption and desorption of $\mathrm{Cd}^{2+}$ and $\mathrm{Zn}^{2+}$ Ions in apatite-aqueous systems. Environ. Sci Technol., 2004, 38 (21), 5626 -5631.

[51] Aleshin, E.; Roy, R. Crystal chemistry of pyrochlor. J. Am. Ceram. Soc., 1962, 45, 18-25.

[52] Roy, R. Multiple ion substitution in the perovskite lattice. J. Am. Ceram. Soc., 1954, 37, 581-588.

[53] LeGeros, R.Z.; Trautz, O.R.; Klein, E.; LeGeros, J.P. Two types of carbonate substitution in the apatite structure. Cell. Molecul. Life Sci. (CMLS)., 1969, 25 (1), DOI 10.1007/BF01903856.

[54] Markgraf, S.A.; Reeder, R.J. High-temperature structure refinements of calcite and magnesite. Am. Mineral., 1985, 70, 590600.

[55] Redfern, S.A.T.; Wood, B.J.; Henderson, C.M.B. Static compressibility of magnesite to $20 \mathrm{GPa}$ : Implications for $\mathrm{MgCO} 3$ in the lower mantle. Geophysic. Res. Lett., 1993, 20, 2099-2102.

[56] Fiquet, G.; Guyot, F.; Itie, J.P. High-pressure X-ray diffraction study of carbonates: $\mathrm{MgCO}_{3}, \mathrm{CaMg}\left(\mathrm{CO}_{3}\right)_{2}$, and $\mathrm{CaCO}_{3} . \mathrm{Am}$. Mineral., 1994, 79, 15-23.

[57] Zhang, J.; Martinez, I.; Guyot, F.; Gillette, P.; Saxena, S.K. X-ray diffraction study of magnesite at high pressure and high temperature. Phys. Chem. Min., 1997, 24, 122-130.

[58] Ross, N.L. The equation of state and high-pressure behaviour of magnesite. Am. Mineral., 1997, 82, 682-688.

[59] Christensen, N.I. Elastic properties of polycrystalline magnesium, iron, and manganese carbonates to 10 kilobars. J. Geophysic. Res., 1972, 77, 369-372.

[60] Deer, W.A.; Howie, R.A.; Zussman, J. Introduction to the rock forming minerals. Churchill ISBN 0582442109, 1972.

[61] Zhang, J.; Martinez, I.; Guyot, F.; Reeder, R. J. Effects of Mg-Fe21 substitution in calcite-structure carbonates: Thermoelas. Pro. Am. Mineral., 1998, 83, 280-287.

[62] Mandell, G.K.; Rock, P.A. Lattice energies of Calcite-structure metal Carbonates II. results for $\mathrm{CaCO}_{3}, \mathrm{CdCO}_{3}, \mathrm{FeCO}_{3}, \mathrm{MgCO}_{3}$ and $\mathrm{MnCO}_{3}$. J. Phys.Chem. Sol., 1998, 59 (5), 703-712.

[63] Reeder, R.; Northrup, P.; Lamble, G.M. Characterization of heavy metal incorporation in Calcite by spectroscopy. J. de Physique IV., 1997, Suppl. 7 C2, 793-797.

[64] Hazen, R.M. Comparative compressibilities of silicate spinels: anomalous behaviour of (Mg,Fe)2SiO4. Science, 1993, 159, 206209.

[65] Kun, Z.; Harel, A.; Stuurman, N.; Guedalia, D.; Gruenbaum, Y.; Im, S.; Powers, E.J.; Sahouli, B.; Blacher, S.; Brouers, F.; Darmstadt, H.; Roy, C.; Kaliaguine, S.; Reeder, R. J. Interaction of divalent Cobalt, Zinc, Cadmium, and Barium with the Calcite surface during layer growth. Geochim. Cosmochim. Acta., 1996, 60 (9), 1543-1552. 
[66] Bodenan, F.; Azaroual, M.; Piantone, P. In: Forecasting the longterm behaviour of municipal solid waste incineration bottom ash: rapid combined tests. Woolley, G.R.; Goumans, J.M.; Wainwright,
P.J., Eds. Waste Materials in construction, Elsevier, Amsterdam, 2000, pp. 475-482.

(C) Meck et al.; Licensee Bentham Open.

This is an open access article licensed under the terms of the Creative Commons Attribution Non-Commercial License (http://creativecommons.org/licenses/by$\mathrm{nc} / 3.0 /$ ), which permits unrestricted, non-commercial use, distribution and reproduction in any medium, provided the work is properly cited. 